\title{
History in the Attic: Search for Roots in Ramabai Espinet's The Swinging Bridge
}

\section{S. Asha}

Associate Professor

Government College Tonk (Raj)

Maharshi Dayanand Saraswati University

Ajmer, Rajasthan, India

sundaramasha5 @gmail.com

Abstract

In most of diaspora literature there is an attempt to retrieve the past. This makes one measure time in many ways, different calendars, change of seasons, past encounters narrated through wars, defeats, encounters and disasters. It is remembered through family history, ancestral heritage, nostalgia, memory and even through national disasters. This interaction portrays the immigrants caught in flight of memories, relationships and images. The relocation has its disgust for one thing or the other. The author has to live in the reminiscences, a collective memory representing a symbolic relationship between past and present. The Swinging Bridge by Ramabai Espinet chronicles the multiple exiles that are part of the Indian experience in the Caribbean and Canada through two figures one from the past- great grandmother Gainder and the other from the present - Mona, the protagonist. The novel commemorates the maternal roots and routes of Indo-Caribbean history by establishing the subjectivity of widows and young girls from India who crossed the Kala Pani (Black waters of the Atlantic) in search of new beginnings in Trinidad and the great-grand-daughter who engages in an existential quest for selfhood in Canada. Grief motivates a flood of personal memories as Mona begins to remember 
intimate details of family life that had been repressed under the cover of migration. Bits and pieces of the past, fragments scattered in various places, childhood memories, overheard conversations, prayer songs, all come together in the attic. She explores the secret songs, photographs and letters giving her a powerful voice for her culture, her family, her fellow women and for herself. Mona's drive to document history enables her to reveal the family's carefully guarded secrets- domestic violence, drunken rampages, sexual abuse, illegitimate children, and even AIDS. This paper seeks to analyse the novel's diasporic contents and find out whether this attempt at retrieval of the past brings about a change in the perception of today's generation. The author brings to light the problems of a plural society calling for need for relationships and need for mutual respect- all to avoid conflict situations through this effective tracing of history in the novel.

Keywords: Diaspora, History, Memory, Oppression, Voice.

Diaspora is a journey towards self-realization, self-recognition, self-knowledge and self-definition. There is an element of creativity present in the diasporic writings and this creation stands as a compensation for the many losses suffered. In most of diaspora literature there is an attempt to retrieve the past. This makes one measure time in many ways, different calendars, change of seasons, past encounters narrated through wars, defeats, encounters and disasters. It is remembered through family history, ancestral heritage, nostalgia, memory and even through national disasters. This interaction portrays the immigrants caught in flight of memories, relationships and images. According to Brij V Lal "A Diaspora exists precisely because it remembers 'the,homeland'. Without this memory... these migrants and settlers would be simply people in a new setting, into which they merge, bringing little or nothing to the new home, accepting in various ways and forms the mores and attitudes that already exist in their new country and society". However these people "do not merely settle in new countries: 
they recreate in their socio-economic, political and cultural institutions a version of that...that homeland they remember" (Lal Brij V.et.al.18). Ramabai Espinet's novel The Swinging Bridge is a retrieval novel through which the author attempts cultural connections to search for her true self. This paper seeks to analyse this novel's diasporic contents and find out whether this attempt at retrieval of the past brings about a change in the perception of today's generation. The author brings to light the problems of a plural society calling for need for relationships and need for mutual respect- all to avoid conflict situations through this effective tracing of history in the novel.

The characteristic features of the diasporic writings are quest for identity, uprooting and re-rooting, insider and outsider syndrome, nostalgia, nagging sense of guilt etc. The diasporic writers turn to their homeland for various reasons. For e g. Naipaul turns to India in a perpetual quest for his roots. Rushdie visits India to mythologise its history. Mistry visits and re-visits India to re-energize his aching soul. Bharati Mukherjee's childhood memories take her back in time again and again. All the same it is necessary to realise the importance of cultural encounter, the bicultural pulls which finally helps in the emergence of the new culture. The diasporic writings also known as the 'theory of migrancy' helps generate aesthetic evaluation, negotiate with cultural constructs and aid the emergence of a new hybridity.

The history in Espinet's novel, The Swinging Bridge is family history as well as the nation's history. Another significant factor is the silencing of history; particularly female voices. Other traces found are those of immigration, cultural oppression, gender oppression, isolation of the marginalized; which all have been taken account of in the novel. Mona, the protagonist plays a special role in as a representative of double diaspora. She is a film researcher living in Toronto after her family migrated to Canada from Trinidad. She is a strong, independent career- minded woman who does not shirk responsibilities. she works for a film company. She wants to research on the role of Cecile Fatiman (who is a neglected Haitian 
historical figure), and include her in her film, but is forced to focus on her own family history. At the start of her story, Mona gets a phone call from her sister, Babs, that their brother, Kello, is dying. Kello tells his family that he is dying of lymphoma, but later reveals that he is actually dying from AIDS. Kello asks Mona to return to Trinidad and buy the family land back. Mona is hesitant, but eventually learns that she was given this opportunity to discover more about her family history, their ancestor's journey from India to Trinidad, and the hardships they have had to face along the way. Throughout the novel, Mona unveils the significance of the historical archive for the history of her family, women, and the greater Indo-Trinidadian culture over the course of several generations and migrations. She gives voice to the marginalized that were silenced by the past and even by her own people. Set in modern times, the novel interconnects the past to the present. As Mona discovers these hidden histories, she also comes to discover herself. The Swinging Bridge serves as a symbol of her life journey and the journey of her ancestors. It is a metaphor. It refers to the precarious position Mona finds herself in. She is poised between the swinging bridge of her Caribbean youth and Canadian adult life. It also stands for the bridge that distanced as well as connected the Caribbean islands to India, the place Mona 's ancestors had left more than a century ago. The connection could be only through cultural memories. Trinidad was also not a very safe refuge for her. She was always consumed with the thought of escape, of leaving Trinidad — for somewhere better. (39).

Mona is accompanied by Bess, her cousin in this journey of exploration as they decide to clean the attic in her ancestral home in Trinidad. They find things which trigger memories from childhood. Her memories are like a film montage of significant settings and incidents such as the magical "enchanted forest" of her early years, the "big row" that changes everything, the Dirty Skirts Club of her adolescence, and various frightening encounters with men. In spite of a personal and collective history of brutality and abuse, Mona emerges as a sensitive and compassionate woman, the perfect individual to "replace the pages torn out from the family 
history.'(23) She explores this historical archive from materials like rare photographs, letters and mementos found the attic. Mona's interest in the family historical archive even as a child is evident from the fact that she desired a camera which was denied to her by her father. She was only allowed to view things passively through the binoculars which was gifted to her. She, as a child could not voice her feelings, neither could her mother do so. In fact, she was even silenced by her mother. This silencing of female voice dated back to history. Her great-grand mother's songs had been silenced. Mona discovers these secret songs of her great-grandmother, which revealed a powerful voice for her culture, her family, her fellow women and herself.

The house that is presented in the two women's memories, during a cleaning of the attic, is one filled with secrets. Songs of the ancestor, Gainder are at the centre of the familial past. There is also rape, abuse and stories of oppressed women. Relations are tangled, hidden, erased, in this version of heteropatriarchal family, in which Bess represents a double illegitimacy as both female and "outside child." Espinet writes, "[s]he dealt in lineage and posterity and generations and descendants. Family was not just breeding and reproducing - it was a work of art in itself, as carved and sculpted as any other legacy that one could leave behind" (123). She battles to become legal heir to her biological father, "no easy task in Trinidad, where legislation about inheriting property was still colonial to its core, ignoring illegitimacy and the straying habits of ordinary people" (Espinet 123). Thus, her struggle to purchase the land directly challenges normative patrilineage. In regaining what would have been Kello's inheritance, Bess acts as surrogate (male) citizen, a necessary accomplice to the absent Kello. She visits the land and captures it in photographs, her camera operating as an "eye" and "I" for both Mona and the male would-be owner who lies incapacitated in another country. Bess walks "to the boundary lines and takes panoramic shots" and envisions its development: "through her eyes I [Mona] saw the property's possibilities and knew that Kello would be pleased" (Espinet 126). The property passes in a shifting pattern of ownership that 
envisions a different kind of citizenship, perhaps: from a family's patriarch, to developers, and then through a queer man's homesickness, via two women's hands to his posthumous possession. Nevertheless, the land will eventually be developed and provide home-sites for Kello's children (he has divorced their mother), and thus still follows a patrilineal line of inheritance.

There is a flood of personal memories, as Mona begins to remember intimate details of family life that had been repressed for several years under the cover of migration. Mona begins to recollect her childhood in San Fernando. Thoughts about the impending trip back "home" and the actual trip itself take Mona further back in time to connect spiritually with Gainder, her great- grandmother. The ancestor's own life had been impacted by a series of dislocations when she was forced to escape an unwanted marriage to an old man, and subsequent early widowhood. The narrator's journeys of memory weave a complicated narrative quilt as Mona attempts to piece together the lost fragments of her family heritage, while reconciling the multiple pasts of her Indo-Caribbean identity. The Swinging Bridge thereby chronicles the multiple exiles that are a part of the Indian experience. The novel commemorates the maternal roots and routes of Indo-Caribbean history by establishing the subjectivity of widows and young girls from India who crossed the kala pani (the black waters of the Atlantic) in search of new beginnings in Trinidad, and the immigrant great-granddaughter who engages in an existential quest for selfhood in Canada. Impacted by the multiple displacements of race, class, gender, identity, tradition, and nationhood, the narrator unravels the representational liminality of Indo-Caribbeanness in Trinidad and Canada through the scope of memory to "confront not only her own past but the secrets of a winding family history begun on the Indian continent almost two centuries ago,"(26)

Mona finds a parcel containing Love letters from 'a bamboo wife' written to her grandfather. Etwaria, the woman who came from India was married to Ganga Singh for about 
two years but had to spend time as recluse because of the cultural rift caused by Ganga Singh's marriage to a Christian, educated girl. Along with these love letters, there is a slip of paper with the words reminding her of Independence Day celebration. There are also letters to editors which Da-Da wrote expressing his views about the government policies and the reality of expatriate existence. Mona traces Trinidadian political history.

Dr.Eric Williams, also known as 'De Doctah' in the novel, was the first and long-time prime minister of independent Trinidad and Tobago from1962-1981.He founded the People's National Movement(PNM) in 1956 and led his country to independence soon after. James was educated at elite universities such as Queen's Royal College in Port of Spain and the University of Oxford, receiving a BA in1932 and a DPhil in1938,with specialization in History and Political Science. By rallying behind the saying 'Massa day done', he won most of his support from Afro-Trinidadians and Calypsonians, while still receiving some votes from whites, and Indo-Trinidadians like Da-Da. De-Doctah claimed his use of 'Massa' was not just referring to the whites, but rather it 'represented a class of persons, an orientation that transcended phenotype or ethnicity.' '(Palmer24)He strongly urged the followers of PNM to embrace 'all races and colours from all walks of life' and in the same speech promised no special privileges would be given to any specific class, race, colour or national origin(Palmer 24).By giving Trinidadians a sense of national stability through independence, and by rallying behind an idea of equality for all races, He won the 1962 election by a landslide. In the year 1963 Mona recalls being consumed by the idea of 'Massa Day done'... We could come into our own. Coming into our own meant celebrating our own culture and not some washed out white people song and dance sent from England (65) To Mona and many other Indo-Trinidadians, Eric Williams and the PNM gave them a sense of promise and excitement that Trinidad would finally be relinquished from English cultural experience. In the Swinging Bridge Da-Da was offered a job by De Doctah in the legislative council where he was promised honours, recognition and 
wealth. Da-Da refused the lucrative job offer saying, 'he couldn't advance himself at the expense of his own people ( Espinet). Although De Doctah promised him power and influence, Da-Da saw himself as, 'an Indian man and a Trinidadian, neither cancelling out the other, a natural inheritor of the Creole culture he loved', and therefore could not align himself with such a corrupt party(69) ).The problem for Dada that arose was De Doctah's partisan display and thus ' had, destroyed any vision of oneness and equality '(69). Instead of joining the country together De Doctah had done exactly the opposite in Mona's opinion. The contradiction of what De Doctah told Trinidadians and what he actually did when in office was too much of a contradiction for many Indo-Trinidadians to bear. Being faced with extreme racism in Trinidad after the false promise of all races being equal and having equal opportunities to advance themselves under the PNM, Mona's family decided to migrate to Canada in hope of a better future.

American military influence was very prevalent during Trinidad's fight for independence. When Trinidad was selected as the site of a federal capital of West Indies in 1957, controversy arose over the US military base at naval base(palmer79). Chaguramas was selected as the perfect site because it was only seven miles from Port of Spain. But the American government insisted on the use of Waller Field which was a de-activated US air force base. Chaguramas assumed a contentious issue but De Doctah backed out on it due to several reasons the main being the spread of violence and adverse cultural impact which the American soldiers brought about.

Ramabai Espinet has repeatedly tried to bring the issue of the inherited unknown and unknowable presence of the 'Indo-Caribbean woman' to the forefront. This 'Indo' in her identity comes first through the remote history of migration of her ancestors from India to the island of Trinidad, along with thousands of others who were brought to the Caribbean island to work as indentured labourers. Her family came to Trinidad in the 1870 s and generations 
later, Ramabai was born in 1948 in Trinidad's San Fernando. She grew up in the island in a Presbyterian-Christian Indian household before being displaced across the seas like her ancestors, this time to Canada. Since then Ramabai's life has been shared between Canada and the Caribbean, and she writes from this perspective of a culturally displaced woman trying to balance the ideas of identity and home. Though Ramabai's works may be analysed best under the heading of 'cultural memory'. She speaks of a vast collective memory related to and rooted in cultures, both Indian and Creole), the starting point remains the point of disjuncture. "A cultural memory that is communicated through stories is an act in the present by which individuals and groups constitute their identities by recalling a shared past on the basis of common, and therefore often contested, norms, conventions and practices'(Hirsch and Smith 2002:5).The collective memories, documented in stories, bear testimony to the immigrant's past and show how subjectivities are negotiated within and adapted to the historical and social circumstance in which women and other subordinate individuals-transsexuals for examplefind themselves(Giles2002:39).

Ramabai's novel The Swinging Bridge (2003) bears testimony to this dislocation and cultural memory. She begins the novel with the Preface 'kala pani' in which she writes, It is an untold story...The records of indentureship to the Caribbean show that Brahmin widows formed an inordinate number of the females who migrated...My foremothers, my own greatgrandmother Gainder, crossing the unknown of the kala pani, the black waters that lie between India and the Caribbean. $(2003,4)$. The protagonist of the novel, Mona Singh, a self-confessed —nowarian (146), a wanderer created by colonisation. A Montreal- based film-maker, Mona lives - in the eye of a storm... (5) She is beset with a sense of drifting, her inner turbulence stems from deep insecurity and the unforgettable scars sustained in her childhood and growing up years as a woman within a migratory Indian family in Trinidad, during the turbulent 1960s. The coloniser's history which Mona has been forced to study, is replete with images of 
imperialists who have shaped the lives of the indentured people by —shoving, herding, transporting... from one end of the earth to another.

In the novel Mona goes further back in time to connect spiritually with Gainder, her great grandmother, in an attempt to establish a sense of historicity. The feeling of this migrant existence is so deep in Mona that even as an adult she failed to see herself functioning the way her parents did in family matters (69). They had not told me enough. I needed more legends, more stories, more knowledge of the past to sustain me. When we were growing up, there were lots of stories... Now I found these tales fading from my memory, in spite of my own drive to document history, to capture these stories somehow. (77) Hence, her fascination with the Ramayana, the story of exile and banishment, of racial and tribal grief (108). As Mona's journal gets juxtaposed with the account of her great-grandmother Gainder in the text, journey becomes a metaphor for the exile of both these women across time Chasing her dreams and running away from an old husband, Gainder had tried to escape to Trinidad in 1879. She was called a 'rand', meaning both a widow and also a 'harlot'. In 1995, when Mona discovers Gainder in the family tree of Grandpa Jamesie's bookcase and discovers her grandmother Lily's reminiscences of her own mother, she develops an instant connection with the nineteenth century woman, a banished woman, alone, her story waiting to be written. Gainder's story and Mona's story merge together and become one, the story of women who found place nowhere. Just as Gainder had refused to conform to the norms of the society, Mona, too, strives towards creating an alternative image of female identity, refusing to be codified by the patriarchal Indian family, and wanting simultaneously the freedom to retain or reject cultural elements from her Indian and Caribbean past, as she weaves these elements into her Canadian present. Like Mona, her creator Ramabai says that she is -intensely aware of my identity as an IndoCaribbean person and my writing cannot help but respond to this (Mehta,24) in) She feels that the Indo-Caribbean community at Trinidad had to pay a heavy price for its conservativeness 
and quietness_— The price of invisibility (104). But the exile' has already been experienced, and the time is now for struggle and survival. The lack of - a placeable sense of identity (Srivastava 1989, 110) adds a fluidity, an indefinability which lends the Indo-CaribbeanCanadian writers a charm of their own and opens up possibilities for further probations and explorations. In such scenario the movement of women becomes even more challenging and ambiguous as they are already under multiple marginalisation of being Diasporic women. Ramabai Espinet, says. "We are not south Asians in a true sense of word we are peculiar hybrid, our cultural world more pronounced than most children of India outside it shores. We, for the most part speak no language but European tongue: English, French or Dutch in its standard form as well as the peculiar version of Creole.”(Mishra in Brij V. Lal et.al. 2006: 130)

In her childhood she had failed to realise her father's frustrations and violent outbursts; the real reasons behind his drinking, gambling and abusing his wife remained incomprehensible by her. She realised later that her father — saw himself both as an Indian and a Trinidadian, a natural inheritor of the Creole culture he loved. But in the end, he had found nothing. (69) His regular letters to newspaper editors in 1964 spoke of discrimination against people of Indian origin which started since 1956 when the new leader Dr. Hector James labelled IndoCaribbeans as a - hostile and recalcitrant minority (70) The adult Mona observes that (182) 'We, and others like us, were living in our own insular world, oblivious of how we appeared to the rest of the society around us. However, protected we had been in our little Presbyterian world in San Fernando, one shove into the bustle of Port of Spain would put us squarely back into our places as country Indians, nothing more. (78) In school the common notion was - how Indian girls were hot hot from small—no wonder they had to marry them off as children, and no wonder wife beating and chopping was so common among those people (140). Thus, when Mona and her friends were caught reading adult comics in school, their teacher Miss Lee considered the act —deplorable yet — predictable, because Indian girls were not civilized or 
creolized' enough. They did not reach the approved standard of proper Trinidad society, they -were hot coolie girls who had to be brought in line (140). The word -coolie was an incredibly loaded racist epithet in the Caribbean for Indo-Caribbean people. It connotes lowstatus and contempt. The racial tensions and blatant discriminations against Caribbean of Indian origin had forced Mona's father to decide to migrate to Canada, - the natural home, perhaps, for Indian/Presbyterian people (99) Canada had opened its doors to people from the Caribbean, making way for the departure of Mona and her family from that - early island home into a Canadian migrant existence (70) The adult Mona later observes in her journal, -All it took then in Trinidad was looking Indian; all it took now in Canada was skin colour. We had not moved one inch (78) In Canada, the place is so deep in race that - people don't even know they doing it. It is automatic... "It must be an inborn nastiness inside them, generations upon generations of them', (100-101).

Espinet shows in her novel how the path of identity formation is more challenging for women due to the levels of marginalisation that they go through the historical and the modern roles that a woman is expected to play which on the surface gives them the illusion of liberation but in to the deep it further brings a new kind of marginalisation. Bess, Gainder, Baboonie are such characters in this novel. Mona's post memories and remanences reveal the importance of the individual, collective and transgenerational memory in the Indo-Caribbean feminist interrogation of history from the establishment to the abolition of slavery to independence. Through Mona's remembrances an new history emerges.

The idea of "re-turn" has often been named the defining characteristic of all diasporas -- "that is, they turn again and again toward the homeland through travel, remittances [...] and by various contingent efforts to maintain other links with the homeland. However, in the case of the Indo-Caribbean Diaspora, which dates from the nineteenth-century history of indenture, this "re-turn" takes different form than it does for many of the more recent diasporas. The 
ancestral homeland India is no longer directly accessible, not only due to the longer historical perspective, but also as their dispersal has been marked by the kala pani - the crossings of the black water of the Atlantic - which radically changed their social formations (for instance, the crossing was equated with loss of Hindu essence such as caste purity; and produced a rupture in the collective memory. This rupture complicates any nostalgic yearnings for the former homeland. Instead of the Indian motherland, it is the sea-passage itself and the negatively denoted "Coolie culture" which developed out of the plantation life to which recent IndoCaribbean narratives turn in order to gain a sense of a distinctive Indo-Caribbean legacy. However, this traumatic past, tainted with violence, which still haunts the present resists easy access. Yet in this novel there is a fine attempt at retrieval through recalling Indian festivals, cuisine, weddings and Hindi language.

The relation of diaspora and memory contains important critical and maybe even subversive potentials. Memory can transcend the territorial logic of dispersal and return and emerge as a competing source of diasporic identity. Anh Hua makes very interesting points about women, memory and diaspora, claiming that diasporic women's practices of remembering and documenting these memories enable marginalized women not only to resist the colonial tropes of victimization of and the Otherness but also to "act as a catalyst for selfdiscovery and community -building.' (205) 


\section{Works Cited}

Agnew, Vijay Diaspora, Memory and Identity: A Search for Home. Toronto: University of Toronto Press,2005.

Espinet, Ramabai The Swinging Bridge New Delhi, Penguin.2004.

Giles, Judy 'Narratives of Gender, Class and Modernity in Women's Memories of Mid-Twentieth Century Britain', Signs: Journal of Women in Culture and Society,28(1):21-41. (2002)

Hua, Anh "Diaspora and Cultural Memory"' in Vijay Agnew, ed. Diaspora, Memory, and Identity: A Search for Home. Toronto: University of Toronto Press, 2005.

Hirsch; Marianne and Valerie Smith “Feminism and Cultured Memory: An Introduction", Signs: Journal of Women in Culture and Society,28(1):1-19. (2002)

Jain, Jasbir Diaspora Writes Home: Subcontinental Narratives. Jaipur, Rawat Publication.2015.

Lal Brij V, Reeves and Rai Encyclopaedia of the Indian Diaspora University of Hawaii Press, 2006:18

Mathur, Charu “ A Narrative of Self-Reclamation: Ramabai Espinet's The Swinging Bridge ''in Literary Constructs of the Self: Socio-Cultural Contexts, eds. Santosh Gupta and Mini Nanda, Jaipur: Rawat Publications,2010,170-178.

Brinda J Mehta Diasporic (Dis)locations:Indo Caribbean Women Negotiate the Kala Pani, University of West Indies Press Kingston Jamaica,2004

Palmer, Colin. A. Eric Williams and the Making of Modern Caribbean. Chapel Hill, The University of North Carolina Press,2006.

Web Resources:

"Engendering History A Poetics of the Kala Pani in Ramabai Espinet's The Swinging Bridge" https://www.researchgate.net/publication/249910453 accessed May 292018.

Historical Context \& Thematic Analysis of Ramabai Espinet's 2003 Novel. https://theswingingbridgeuf.wordpress.com. 
The Intersection of Memory and History: Memories of Physical and Sexual Violence in Ramabai Espinet's The Swinging Bridge. www.academia.edu. 